\title{
Port Denials and Restrictions Policies during Covid-19 Pandemic Based on International Law
}

\author{
Angela Jessica Desmonda ${ }^{*}$ \\ DOI: https://doi.org/10.22304/pjih.v7n3.a5
}

Submitted: August 07, 2020 | Accepted: September 30, 2020

\begin{abstract}
As a public facility, port has a significant potential to be cluster of the Covid-19 spread. Many states have implemented policies of denials and restriction of port access to protect people's health. This study aims to analyze port denials and restrictions policies settings based on international law. In addition, this study is to analyze whether the status of state of emergency will affect state's obligations based on international law. This study was conducted by analyzing associated international treaty law and customary law. The study concludes that no international treaty law and customary law prohibit port denials and restrictions because port is under the sovereignty of respected coastal state. The state is free to implement any policies. Without any permit, foreign ships are not allowed to enter and dock at the port of the coastal state. However, in a situation of danger or distress, foreign ships have the right to enter port. The IHR 2005, as a special instrument dealing with public health, also provides an opportunity for coastal state to prevent ship embarking and disembarking passengers if the ship is exposed to a pandemic disease, such as Covid19. In such case, foreign ship may be prohibited from entering and docking at port of coastal state. On the other hand, in a situation of danger or distress, foreign ship has the right to enter port. In contrast, the 1923 Port Convention gave permission to state to close ports in urgent situation that endangered national security.
\end{abstract}

Keywords: Covid-19 pandemic, port denials and restrictions, state of emergency.

\section{Kebijakan Penolakan dan Pembatasan Pelabuhan Selama Pandemi Covid-19 Berdasarkan Hukum Internasional}

\begin{abstract}
Abstrak
Pelabuhan merupakan salah satu akses masuknya kapal asing ke suatu negara dan juga dapat menjadi akses masuk bagi penyebaran pandemi Covid-19. Demi melindungi kesehatan masyarakatnya, banyak negara menerapkan kebijakan penolakan dan pembatasan akses pelabuhan. Artikel ini bertujuan untuk menganalisa pengaturan kebijakan port denials dan restrictions dalam kerangka hukum internasional. Selain itu, penelitian ini juga akan menganalisa bilamana status State of Emergency yang dideklarasikan oleh negara akan mempengaruhi kewajiban dalam hukum internasional terkait dengan kebijakan port denials and restrictions. Penelitian ini dilakukan dengan
\end{abstract}

PADJADJARAN Journal of Law Volume 7 Number 3 Year 2020 [ISSN 2460-1543] [e-ISSN 2442-9325]

Magister Candidate of the Faculty of Law, Universitas Padjadjaran, Jalan Dipati Ukur Nomor 35 Bandung, S.H. (Atma Jaya Catholic University of Indonesia), angela.jessica29@gmail.com 
melakukan analisa terhadap hukum perjanjian internasional dan hukum kebiasaan internasional terkait. Penelitian ini menunjukan bahwa tidak ada hukum perjanjian internasional dan hukum kebiasaan internasional yang melarang kebijakan penutupan dan pembatasan akses pelabuhan suatu negara pantai. Hal ini dikarenakan pelabuhan berada di dalam yurisdiksi negara pantai di mana negara tersebut bebas untuk menerapkan kebijakan apapun. Tanpa adanya izin, kapal asing tidak diperbolehkan untuk masuk dan berlabuh di pelabuhan negara pantai. Meskipun demikian, dalam keadaan bahaya atau kesulitan, kapal asing memiliki hak untuk masuk ke dalam pelabuhan negara pantai. IHR 2005 sebagai instrument khusus yang menangani kesehatan publik juga memberi celah bagi negara pantai untuk melakukan pencegahan masuknya kapal untuk menaik-turunkan penumpang jika dirasa kapal tersebut terpapar Covid-19. Bahkan, Port Convention 1923 memberikan izin kepada negara untuk menutup pelabuhannya dalam keadaan mendesak yang membahayakan keamanan negara.

Kata kunci: keadaan darurat negara, pandemi Covid-19, penolakan dan pembatasan pelabuhan.

\section{A. Introduction}

Port is one of access points for people and goods to enter into a state. Therefore, it is a main control points for customs, immigration, public health, and national security purposes. ${ }^{1}$ Mostly, national security is associated with military strength and national defense. In spite of this, following the Covid-19 pandemic, the field of national security has experienced drastic changes, akin to health. From the perspective of the Covid-19 pandemic, national security covers a protection from disease infections and health problems that potentially threaten national economy, people's lives, and political system. ${ }^{2}$

Numerous states have declared a 'state of emergency' due to the increasingly out-of-control spread of the Covid-19. Over the past few months, a number of states' authorities have implemented massive travel restrictions to control the pandemic. Such limitation certainly has clear reasons. One of the main factors contributing to the pandemic is globalization, in particular international trades, and travel, which can accelerate and facilitate the spread of disease. The implementation of the policy of port denials and restrictions is expected to help controlling the spread of the disease and decreasing the number of death rate.

No article of UNCLOS 1982, as well as or any other international legal instruments, explicitly prohibits port denials and restrictions during a pandemic. In fact, UNCLOS 1982 does not mention pandemic specifically as a threat to national security and further regulate the rights and obligations of coastal states and ports

\footnotetext{
Erik J. Monelaar, "Port and Coastal States" in Donald R. Rothwell (Ed.), (et.al), The Law of the Sea, United Kingdom: Oxford University Press, 2015, p. 282.

Sara E. Davies, "National Security and Pandemics", UN Chronicle, https://www.un.org/en/chronicle/article/national-security-and-pandemics, accessed on September 2020.
} 
during pandemic. Based on the principle of lex specialis derogate lex generali, special legal instrument can be considered as a point of reference.

This article aims to review the issue, considering the moment, to review existing policies related to port denials and restrictions in the context of the current pandemic. Several questions have arisen because of port denials and restrictions policies. This article aims to review existing policies relating to port denial and restrictions in the context of the ongoing pandemic. Several important points are discussed in this article. The first is the circumstances for state's jurisdiction to implement a 'state of emergency' and the possibility of the Covid-19 Pandemic as a valid reason for "state of emergency". The second is the use of state-of-emergency status to enforce port denials and restrictions, considering several states have already done it. Finally, this article also covers safety at sea -particularly search and rescue issues.

In line with the purpose of the study, some analyses have been conducted to review related international legal instruments such as UNCLOS 1982, IHR 2005, SOLAS Convention, and some other Conventions issued by IMO related to disembarkations. Apart from the analyses, this study talks over customary international law, some theories related to state of emergency, and their relationship to international law. To end with, this study seeks to propose recommendations for possible future policies, or ideal legal conditions, to ensure better protection of rights at sea.

\section{B. The Beginning of Port Denials and Restrictions Policies}

Following the first outbreak in Wuhan, Hubei Province, China, a new type of corona virus named novel coronavirus (2019-nCov or Covid-19) has attracted worldwide attention. The alleged cause of the emergence of Covid-19 is related to contact with wild fish and animal market at the Huanan Seafood Wholesale Market that sells live animals. ${ }^{3}$ Covid-19 is a type of corona virus that is dangerous and threatens human lives. This virus can cause fever, breathing problems, and cough. It is a virus attacking the human lungs. ${ }^{4}$ After the discovery of the virus at the end of December 2019 to June 5, 2020, there had been at least 6,535,354 positive cases and 387,155 deaths worldwide due to Covid-19. Details of positive cases and deaths along with their distribution maps can be seen in Table 1, Figure 1, and Figure 2.

Fengxiang Song (et.al), “Emerging 2019 Novel Coronavirus 2019-nCov) Pneumonia”, Radiology, 2020, p. 210. Ibid. 
Table 1. Total Positive Cases and Deaths Due to Covid-19 as of 5 June $2020^{5}$

\begin{tabular}{|l|c|c|}
\hline Global & $6,535,354$ Cases $(118,526)$ & 387,155 Deaths $(4,288)$ \\
\hline Africa & 121104 Cases $(5,465)$ & 2958 Deaths $(100)$ \\
\hline America & 3084517 Cases $(61,693)$ & 172276 Deaths $(3,723)$ \\
\hline Eastern Mediterranean & 587030 Cases $(17,004)$ & 13720 Deaths $(262)$ \\
\hline Europe & 2230706 Cases $(19,558)$ & 182165 Deaths $(-143)$ \\
\hline South-East Asia & 322863 Cases $(13,266)$ & 8942 Deaths $(332)$ \\
\hline Western Pacific & 188393 Cases $(1,540)$ & 7081 Deaths $(14)$ \\
\hline
\end{tabular}

Figure 1. Map of the Confirmed Covid-19 Outbreak from May 30, 2020 to June 5, $2020^{6}$

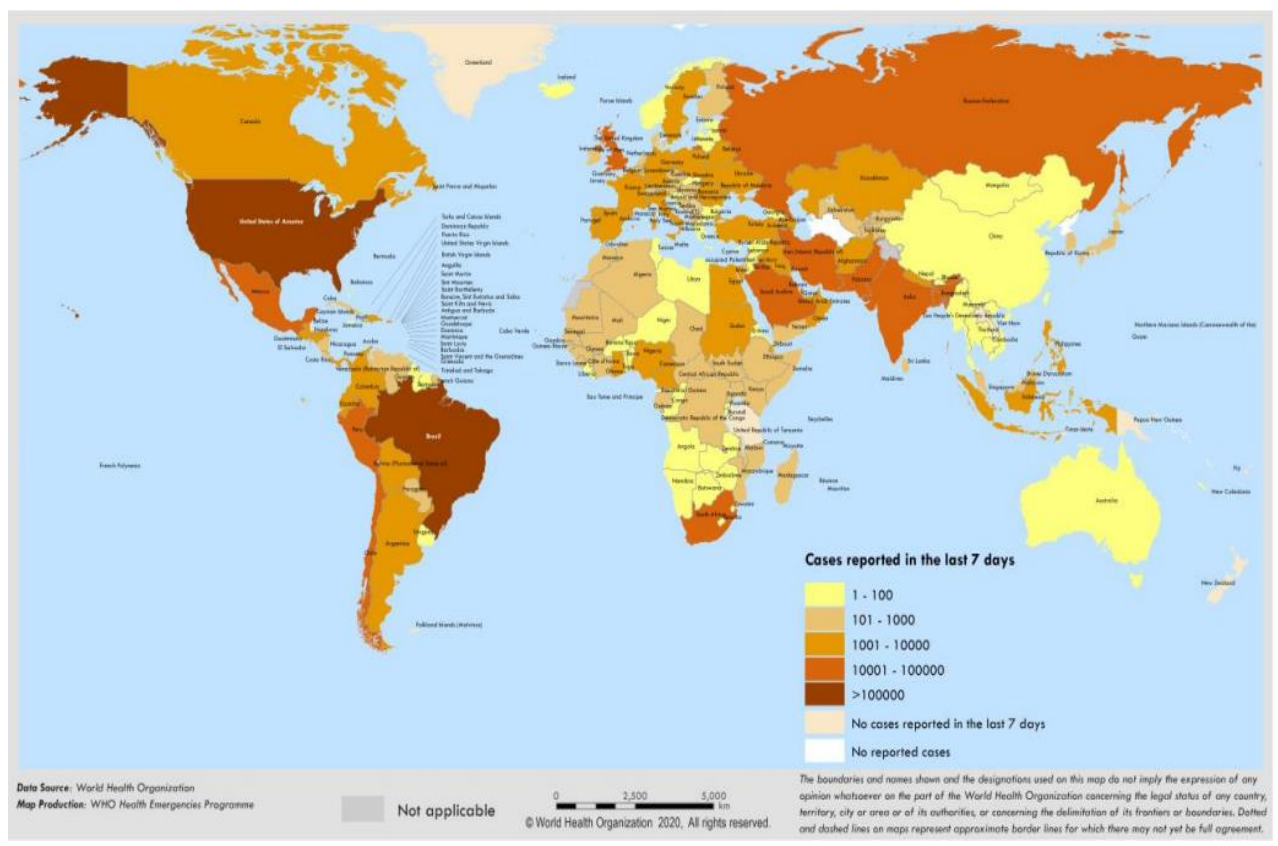

5 World Health Organization (WHO), "Coronavirus Disease (Covid-19)", Situation Report-137, 5 Juni 2020, p. 1, https://www.who.int/docs/default-source/sri-lanka-documents/20200605-covid-19-sitrep137.pdf?sfvrsn=a13df572_2, accessed on September 2020. Ibid., p. 3. 
Figure 2. Graph of Covid-19 Cases in the WHO Region from December 30, 2019 to June $5,2020^{7}$

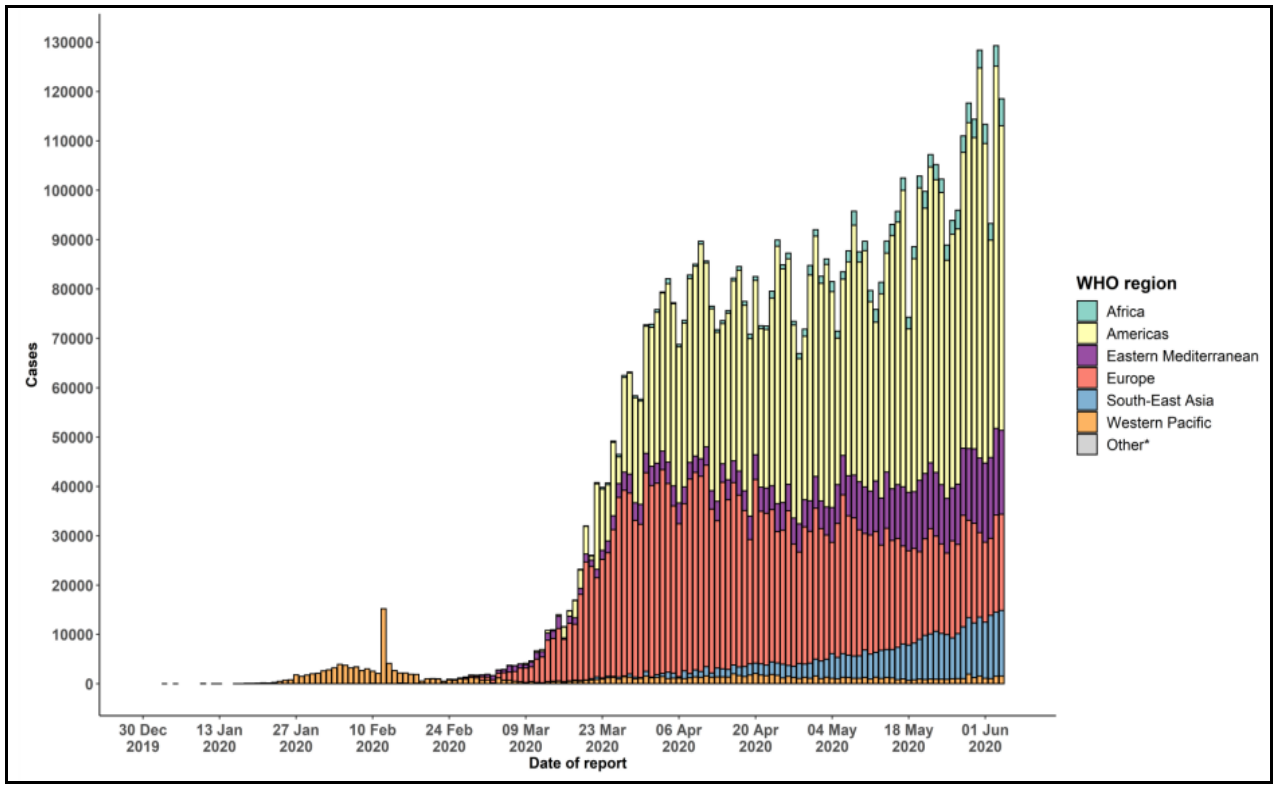

Based on the data, it is not surprising that the World Health Organization (WHO) declared Covid-19 a global pandemic on March 11, 2020. The status of a global pandemic indicates that the virus has crossed borders of states and continents. It has affected all people. ${ }^{8}$ Prior to Covid-19, there had been several pandemics. One of them is the 1918 Spanish Influenza pandemic that infected more than a third of the world's population and killed an estimated 50 million people, and H1N1 in 2009. ${ }^{9}$

The unrestrained spread of the virus has generated devastating effect on affected states. Many states have declared a state of emergency due to the Covid19 pandemic, such as the United States, Japan, Spain, and Indonesia. The "Emergency" status usually allows a system of temporary management to handle extremely dangerous or difficult situations. ${ }^{10}$ All states are affected by Covid-19 and facing difficult situations due to the Pandemic. The virus affects various fields, such as health, education, and tourism. The biggest impact is economy for sure. The Covid-19 does not only affect economic papers but also economic activities, like shipping. Concern of a greater spread of the virus has prompted states to

\footnotetext{
Ibid., p. 4.

8 Carlo Caduff, The Pandemic Perhaps: Dramatic Events in A Public Culture of Danger, California: University of California Press, 2015, p. 96.

Dara Grennan, "What is a Pandemic?", JAMA Patient Page, Vol. 321, No. 9, 2019, p. 910.

10 Cambridge Dictionary, "State of Emergency", https://dictionary.cambridge.org/dictionary/english/state-ofemergency, accessed on May 2020.
} 
implement port denials and restrictions. Previously, in 2014-2016, when the Ebola Virus Disease (EVD) epidemic emerged in West Africa, many states closed down and restricted access to their ports to prevent infection.

Following the Covid-19 outbreak, state has begun to delay and refuse to grant permission for ships to enter ports. This disrupts shipping traffic and affects not only the ship but also its crew, passengers, and cargo. Many states anticipate that passengers infected with the Covid-19 virus enter their territory, so they take steps to limit access. Figure 3 below show the states implementing the policy.

Figure 3. Map of the Distribution of Covid-19 Port Restrictions Worldwide as of June $7,2020^{11}$

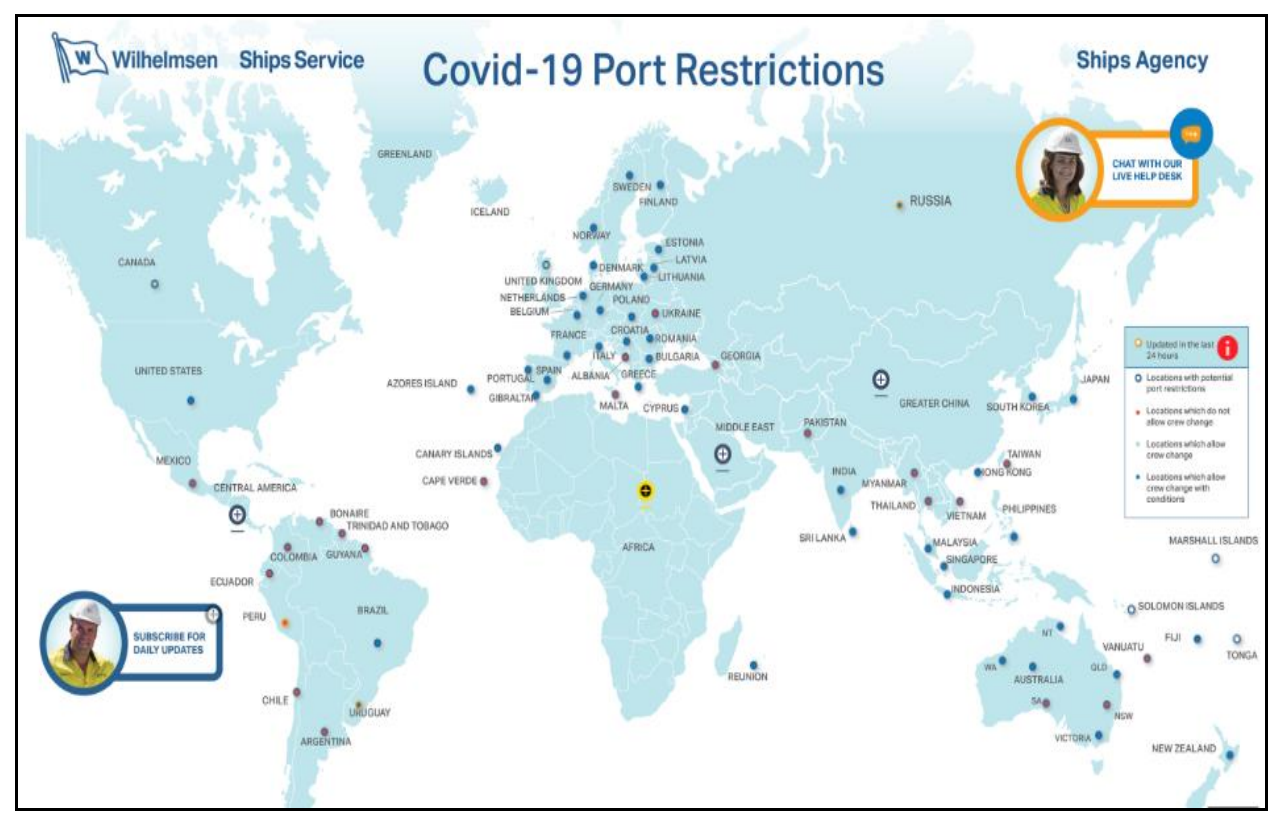

Most ports have provided circular or notices with some guidelines for port entry restrictions, such as delaying port entry permits, preventing crew members or passengers from boarding (including preventing ground leave and crew changes), preventing cargo loading, refueling, and restocking food supplies. In extreme cases, states also implement quarantine and refusal of ships. The efforts are good to prevent contamination of the Covid-19. However, port denials and restrictions can adversely affect shipping aspects such as the cargo supply chain and crewmembers. It can affect the shipping industry since international trade traffic is disrupted.

11 Willhelmsen, “COVID-19 Global Port Restrictions Map”, https://www.wilhelmsen.com/shipsagency/campaigns/coronavirus/coronavirus-map/, accessed on June 2020. 


\section{Mare Liberum vs. Mare Clausum and Port Access Rights}

With regard to international maritime law, the principles of Mare Liberum and Mare Clausum are related closely to the maritime zone, which will have an impact on the sovereignty and sovereign rights of a state.

The principle of Mare Liberum or 'the Freedom of the Seas' was introduced by Hugo Grotius (1583-1645), one of the founding fathers of international law. Grotius argues that sea is open to everyone and no state can occupy or claim its sovereignty. His argument is strengthened by the idea that no state can deny foreign ships' access to enter ports. States that deny foreign ships access to their ports are deemed to have neglected the advances in international interaction, navigation, and trade imposed by customary international law. ${ }^{12}$ No state can develop independently without relationship with other states, especially in economy and trade. States need to open access to foreign ships to their ports to conduct international trade. There are reasons for access rights of foreign ships to ports of any states as follows. ${ }^{13}$

1. Every state has freedom to travel and trade.

2. Port denials and restrictions have an impact on economic development and international relations.

3. Port development for trade and maritime security should be provided for traders.

4. State is allowed to deny access rights to ports in emergencies such as war, quarantine, etc.

5. Customary international law allows rights of access to ports.

Based on the above description, in certain emergencies, state is allowed to deny port access rights. Therefore, in the current pandemic situation, the Mare Liberum principle allows states to deny access to their ports.

Contrary to Mare Liberum, the principle of Mare Clausum or Closed Sea considers that sea, ocean, or other waters are under jurisdiction of state and cannot be accessed by other states. UNCLOS 1982 uses the Mare Clausum principle to regulate internal waters and territorial seas. Internal waters and territorial seas come under the jurisdiction of coastal state. Based on this principle, foreign ships cannot enter internal waters, including ports, if they do not have permission from the respective state.

Many experts argue that states have the right to deny foreign ships access to their ports. In the case of 1958 Saudi Arabia v. The Arab American Oil Company (ARAMCO), the Court declares,

\footnotetext{
12 Abdulkadir O. Abdulrazak and Sharifah Zubaidah Syed Abdul Kader, "Right of Ship Access to Port under International Law: All Bark with No Bite”, Australian Journal of Basic and Applied Science, Vol. 6, No. 11, 2012, p. 213.

13 lbid.
} 
"According to a great principle of public international law, the ports of every state must be open to foreign merchant vessels and can only be closed when the vital interest of the states." ${ }^{\prime 14}$

The Tribunal recognized the importance of state sovereignty in controlling ports and its access during certain situations. This is in line with the 1923 Port Convention that gives permission for a state to deviate from the principle of equal treatment among ships at sea in case of an emergency affecting the state's safety or vital interests. ${ }^{15}$ Then, in emergencies, like the current Covid-19 pandemic, state can close ports. It can be concluded that the principles of Mare Liberum and Mare Clausum allow states to implement policies of denial and restriction of ports in urgent or emergency situations that may endanger their territory.

\section{State Emergencies and International Law}

On March 11, 2020, the WHO declared Covid-19 as a pandemic. A pandemic is defined as "an epidemic that occurs around the world, or over a very large area, crosses international borders and usually affects large numbers of people". ${ }^{16}$ As mentioned earlier, when the Covid-19 pandemic began to run out of control, some states, such as the United States, Japan, Spain, and Indonesia, had declared a "state of emergency". State of emergency is a system of temporary regulations for dealing with extremely dangerous or difficult situations. To be more precise, state of emergency originates from a government declaration made in response to extraordinary situations constituting a fundamental threat. ${ }^{17} \mathrm{~A}$ state of emergency can suspend the normal functioning of government, require and remind citizens to change their normal behavior, or empower government agencies to implement emergency preparedness plans and limit or suspend civil liberties and human rights. ${ }^{18}$ State of emergency can only be carried out if it arises from various situations, such as armed action against state by internal or external elements, natural disasters, civil unrest, disease outbreaks, financial or economic crises, or general strike. The qualification of a public emergency must threaten "the life of

14 William D. Baumgartner and John T. Oliver, "Conditions on Entry of Foreign-Flag Vessels into US Ports to Promote Maritime Security", in Michael D. Cartsen, International Law and Military Operations, Rhode Island: Naval War College, 2008, p. 35.

15 Article 16 of 1923 Port Convention reads as follows.

"Measures of a general or particular character which a Contracting State is obliged to take in case of any emergency affecting the safety of the State or the vital interests of the State may, in exceptional cases, and for as short a period as possible, involve a deviation from the provisions of Article 2 to 7 inclusive; it being understood that the principles of the present statute must be observed to the utmost possible extent."

Convention and Statute on the International Regime of Maritime Ports 1923 is adopted in Geneva on December 9, 1923. It entered into force on July 26, 1926, compliant with article 6.

16 Last JM (ed.), A dictionary of Epidemiology, 4th edition, New York: Oxford University Press, 2001.

17 DCAF, "State of Emergency", Backgrounder: Security Sector Governance and Reform, 2005, p. 1.

18 Ibid. 
the nation". This is intended to limit the possibility of abuse by state power. ${ }^{19}$ In the case of the Covid-19 pandemic, state can impose state of emergency.

Afterwards, a state of emergency may have the potential to affect state's obligations under international law. Each state may be subject to different international legal obligations with respect to emergencies. Several problems can determine state obligations. First problem stands around obligations under customary international law binding states. ${ }^{20}$ Second problems cover the status of state as a party to international treaties containing restrictions on emergency. ${ }^{21}$ Typically, treaties that contain restrictions on emergency powers are related to human rights legal instruments. They are, among others, the American Convention on Human Rights (ACHR), the European Convention on Human Rights (ECHR), the African Charter on Human and Peoples Rights (AFHR)), the universal UN human rights treaties, and international humanitarian treaties (in particular the four 1949 Geneva Conventions and the two 1977 protocols).

Four of the treaties have a reduction clause and legally allow temporary suspension of rights during a national emergency: (1) the International Covenant on Civil and Political Rights (ICCPR), (2) the American Convention on Human Rights $(A C H R)$, (3) the European Convention on Human Rights (ECHR), and (4) the European Social Charter (ESC). ${ }^{22}$ The ICCPR, established in 1976, is a legally binding legal instrument. Many scholars argue that at least some of the obligations contained in the ICCPR reflect customary international law. ${ }^{23}$ Therefore, for nonstate parties, the ICCPR is often used as evidence of customary international law and principles of general law. The three others (ACHR, EHCHR, and ESC) also contain certain rights. The rights cannot be limited under any circumstances. They $\operatorname{are}^{24}$

1) The right to life, the prohibition of slavery and torture, and freedom from retroactive regulations;

2) The right to legal personality, freedom of thought and religion;

3) The prohibition of imprisonment for inability to fulfill contractual obligations;

4) The prohibition of the use of the death penalty even in times of crisis and protection from ne bis in idem or double jeopardy;

\footnotetext{
19 Dominic McGoldrick, "The Interface between Public Emergency Powers and International Law", Oxford University Press and New York University School of Law, Vol. 2, No. 2, 2004, p. 393.

20 Jaime Oraa, Human Rights in States of Emergency in International Law, United Kingdom: Oxford University Press, 1992, p. 214.

21 Ibid.

22 Beth Simmons, "Civil Rights in International Law: Compliance with Aspects of the International Bill of Rights", Indiana Journal of Global Legal Studies, 2009, Vol. 16, No. 2, p. 3.

23 Cassandra Emmons, "International Human Rights Law and COVID-19 State of Emergency", Verfassungsblog on Matters Consititutional, https://verfassungsblog.de/international-human-rights-law-and-covid-19-statesof-emergency/, accessed on September 2020.

24 Article 4 (2) ICCPR; Article 15 (2) ECHR; Article 27 (2) ACHR.
} 
5) The demand of constant adherence to humane treatment while in detention, freedom from forced labor, rights of children and families, rights to name and nationality, and right to participate in government.

Human rights law is of little help in defining a state of emergency and only limits the means. This means the government of a state can unilaterally decide whether Covid-19 is a threat that need emergency rule. Once they have it, international human rights law allows the limitation of any rights except those deemed irreducible. Therefore, the policies carried out by the government in responding to the dangers of Covid-19 such as placing restrictions on freedom of information; closing schools, businesses, and places of worship in the name of public safety; and limiting people's freedom of movement that also covers port denials and restrictions are allowed and not prohibited in a pandemic situation.

\section{E. Port and United Nations Convention on the Law of the Sea (UNCLOS) 1982}

Over the past few months, the world has faced tremendous experience. The global order that previously seemed "well-established" is now starting to face challenges. In the field of maritime law perspective, the challenges in question include, for example, cruise ships and the impact of the Covid-19 pandemic on port denials and restrictions policies.

Port is a part of internal waters that are exclusively under the sovereignty of coastal state. UNCLOS 1982 uses the term internal water to describe the waters that lie on the landside of the baseline marking the start of the territorial sea. The legal status of the internal waters of a state is absolute and undeniable. Coastal state has complete sovereignty and control over its internal waters. Therefore, coastal state can establish and carry out actions. Foreign ships have no special right to enter the internal waters of a state, except under customary international law to seek temporary protection in situations where the ship is in danger. Foreign ships intending to enter the internal waters of another state, for example for shipping activities or trade, must obtain a permit to be able to embark or disembark passengers or cargo. Unfortunately, access to internal waters and the port facilities are not discussed specifically and in detail in the UNCLOS 1982. In fact, the policy of port denials and restrictions does not occur only in the ongoing Covid-19 pandemic. Previously, there had been a number of port denials and restrictions imposed by several states. The most familiar is the MV Tampa case in 2001. Australia refused MV Tampa, which brought 433 refugees into their port. ${ }^{25}$

Since the policy of port denials and restrictions is so easy to implement in nonurgent situations, it is not surprising that many states implement the policy today. One that has received attention is Panama's decision to prevent the MS Zaandam

25 Hardi Alunaza (et.al), "The Pacific Solution as Australia's Polucy Towards Asylum Seeker and Irregular Maritime Arrivals (IMAS) in the John Howard Era", Jurnal Ilmiah Hubungan Internasional Universitas Parahyangan, Vol. 14, No. 1, 2018, p. 66. 
cruise ship transiting through the Panama Canal to disembark its passengers in Florida. This problem arose because UNCLOS 1982 did not have a legal framework governing travel via international channels, in this case the Panama Canal. Therefore, the Panamanian authorities acted under the jurisdiction of their territory and refused MS Zaandam to transit. MS Zaandam was allowed to pass through the Panama Canal not because of the UNCLOS 1982 legal framework, but for "humanitarian reasons". ${ }^{26}$ This incident shows that the UNCLOS 1982 drafters do not provide a comprehensive legal framework to deal with emerging problems, such as the Covid-19 pandemic situation which then resulted in the entry of foreign ships into ports through international canals. ${ }^{27}$ Obviously, there are still legal loopholes from the UNCLOS 1982 related to health problems, especially in the maritime sector. UNCLOS 1982 may not be made in detail for various reasons and other legal instruments may cover the deficiencies of the UNCLOS 1982. However, it should be realized that this is a challenge for international maritime law since there are currently issues that must be regulated.

\section{F. Ports and International Customary Law}

In addition to the UNCLOS 1982, customary international law also recognizes that coastal states have sovereignty over ports and internal waters. There is no right to enter a port of a state under customary international law. ${ }^{28}$ This is stated in the decision of the International Court of Justice (ICJ) in the case of Nicaragua v. United States that, "it is by virtue of its sovereignty that coastal state may regulate access to its ports." ${ }^{29}$ This means that a state can refuse the entry of foreign ships into its port. On the other hand, for humanitarian and safety reasons, it is generally recognized that any foreign ship in trouble or danger has the right to enter a foreign port under customary international law. ${ }^{30}$ In this regard, the United States agrees that under the doctrine of force majeure, foreign ships can enter ports under customary international law. The purpose is not only for the sake of the ship's cargo but also the humans on board. ${ }^{31}$

26 Patrick Greenfield and Erin McCormick, "Coronavirus: Panama to Allow Cruise Liner Zaandam through Canal", https://www.theguardian.com/world/2020/mar/29/coronavirus-panama-to-allow-cruise-liner-zaandamthrough-canal, accessed on September 2020.

27 David Letts, "Can the Law of the Sea Remain Afloat During Covid-19?", Australian National University, 2020, https://law.anu.edu.au/research/essay/covid-19-and-international-law/can-law-sea-remain-afloat-duringcovid-19, accessed on September 2020.

28 Yoshifumi Tanaka, The International Law of the Sea, Cambridge: Cambridge University Press, 2012, p. 80.

29 Case Concerning Military and Paramilitary Activities in and against Nicaragua (Nicaragua v. United States), 1986, p. 111, para. 213.

$30 \quad$ Yoshifumi Tanaka, op.cit., pp. 81, 117.

31 United States Department of State, Office of the Legal Adviser, "Digest of U.S. Practice in International Law", 2007, pp. 650-651, www.state.gov/documents/organization/147120/pdf; "Collection of Sources on Entry into Port Under Force Majeure," 2001-2009.state.gov/s/l/2007/112701.htm, accessed on September 2020. 


\section{G. Disembarkation of Persons in Distress at Sea}

Assisting persons in distress at sea is the main principle of life in the sea. ${ }^{32}$ It is also an ancient international obligation and is one of the traditional features of the law of the sea. This rule covers all ships and people, irregular maritime migrants. These have been codified into legally binding international treaties, for example the UNCLOS 1982. Article 98 (2) UNCLOS 1982 reads as follows.

"Every coastal state shall promote the establishment, operation and maintenance of an adequate and effective search and rescue service regarding safety on and over the sea and, where circumstances so require, by way of mutual regional arrangements cooperate with neighboring states for this purpose."

The word "shall" in Article 98 (2) has a clear meaning, namely that state is legally forced to carry out rescue, not only given the responsibility of providing help. Although this provision is contained in Chapter VII UNCLOS 1982, which regulates the high seas, it is generally accepted that the obligation to provide assistance at sea is valid regardless of the maritime zone because the terminology 'any person found at sea in danger of being lost' provides a broad and comprehensive interpretation, not limited to one maritime zone. ${ }^{33}$ This means that, in any maritime zone, all states have a responsibility of to assist ships and people who are in danger.

The UNCLOS 1982 does not go into more detail about this. The refinement of the UNCLOS 1982 arrangement was then refined with a more detailed agreement regulated under the auspices of the IMO, namely the SAR Convention and the SOLAS Convention. In 2004, due to the MV Tampa case, these two conventions were amended; and they oblige states parties to work together and to coordinate ensuring them to make sure rescued persons to safety. The place of safety in question is a location where rescue operations are deemed to have ended. It is a place where the life safety of the persons in distress at sea is no longer threatened and where basic human needs (such as food, shelter, and medical needs) can be fulfilled. ${ }^{34}$

In an attempt to make disembarkation, it should be noted that there are two general principles governing disembarkation. First, based on state sovereignty, foreign ships are not entitled to enter ports of a state. Therefore, to disembark persons in distress at sea to a port, a ship must obtain approval from that port state

\footnotetext{
32 B. H. Oxman, "Human Rights and the United Nations Convention on the Law of the Sea" , Columbia Journal of Transnational Law, Vol. 36, 1997, p. 414. Martin Ratcovich, op.cit., p. 4.

34 The International Maritime Organization “IMO”, Resolution MSC. 167 (78), adopted on 20 May 2004, para. 6.12 .
} 
to enter its port. ${ }^{35}$ Second, the principle of non-refoulement prohibits people from being returned to national borders where they can be threatened or tortured. The problem will arise when after carrying out a rescue; a rescue ship must take the persons in distress at sea to a state as a place of safety. There may be a dispute over whether the state should accept the persons. ${ }^{36}$ This is common in cases of migrants at sea, including refugees and asylum seekers, because the state does not want to take responsibility.

On the other hand, the existing arrangements in the instruments under the IMO do not cover the issue of which states should survivor of the sea be located. For instance, the SAR Convention, the 2004 amendments, clarifies the following state's obligations.

"Parties shall co-ordinate and co-operate to ensure that masters of ships providing assistance by embarking persons in distress at sea are released from their obligations with minimum further deviation from the ships' intended voyage, provided that releasing the master of the ship from the obligations does not further endanger the safety of life at sea. The Party responsible for the search and rescue region in which such assistance is rendered shall exercise primary responsibility for ensuring such co-ordination and co-operation occurs, so that survivors assisted are disembarked from the assisting ship and delivered to a place of safety, taking into account the particular circumstances of the case and guidelines developed by the [Intergovernmental Maritime Consultative] Organization. In these cases, the relevant Parties shall arrange for such disembarkation to be effective as soon as reasonably practicable."

The stipulations assume that relevant states will coordinate and, while a state responsible for the SAR zone has primary responsibility, this responsibility is concerned solely with "ensuring such coordination and cooperation takes place". ${ }^{37}$ This certainly provides an opportunity for a state to refuse the status of a place of safety.

\section{H. The Role of the International Maritime Organization (IMO) in the Current Situation}

The Covid-19 pandemic has attracted international organizations, such as the World Health Organization (WHO) and the International Maritime Organization (IMO). The WHO is tasked with disseminating information and knowledge related

\footnotetext{
35 Richard Barnes, "The International Law of the Sea and Migration Control", in Bernard Ryan and Valsamis Mitsilegas (eds), Extraterritorial Immigration Control: Legal Challenges, Leiden: Martinus Nijhoff, 2010, p. 118.

36 Irini Papanicolopulu, "The Duty to Rescue at Sea, in Peacetime and in War: A General Overview", International Review of the Red Cross, Vol. 98, No. 2, 2016, p. 500. Ibid.
} 
to the virus, tracking the spread of the virus, and providing advice to states, and the international community on health protection and prevention of virus transmission. ${ }^{38}$ Meanwhile, the IMO has the role of providing information and preventive directions to minimize transmission of Covid-19 to crew members, passengers, and others.

On February 13, 2020, the IMO and the WHO released a joint statement to respond to states' decisions to close ports. The joint statement emphasizes the balance that must be achieved between the sustainability of maritime activities and protection of public health for coastal state. ${ }^{39}$ At the same time, the International Shipping Chamber (ISC) also asked coastal states to accept all ships to unload their cargo and passengers, as well as to facilitate their handling.

During the current pandemic situation, states have begun to restrict access to their ports. The IMO is particularly paying attention to seafarers who are a major milestone in the delivery of vital goods, including medical supplies and foodstuffs. The IMO as a competent organization in the maritime sector approved a new protocol (the Circular Letter Number 4204/Add.14) on May 5, 2020, entitled Coronavirus (Covid-19) - Recommended Framework of Protocols for Ensuring Safe Ship Crew Changes and Travel during the Coronavirus (Covid-19) Pandemic. ${ }^{40}$ The Circular contains protocols for joining ship (from ordinary residence of seafarer in one state via aircraft to join ship in port of another state) and for leaving ship and repatriation (from a seaport in a state by aircraft to the ordinary residence of seafarer in another state). In short, the Circular explains how crewmembers can join ships from the state they live in, how they can disembark, and how to return home safely. However, the Circular Letter is not a binding legal instrument and, therefore, cannot force states parties to comply.

The IMO has not provided further explanation regarding the obligations of coastal state in dealing with Covid-19 Pandemic. The IMO calls on coastal states not to prevent foreign ships from entering their ports so as not to disrupt shipping traffic. However, no legally binding instrument from the IMO prohibits coastal states from closing their ports.

\section{International Health Regulation 2005 (IHR 2005)}

In the Covid-19 situation, coastal state certainly performs its best to maintain the health of its citizens. State must ensure that a pandemic does not spread in its territory, while trying to fulfill its obligations to passengers and crew. Therefore, in the current pandemic situation, regulations are needed. As stated earlier, no

38 IMO, A Joint Statement on the Response to the Covid-19 Outbreak between International Maritime Organization (IMO) and World Health Organization, 13 February 2020, http://www.imo.org/en/MediaCentre/HotTopics/Documents/Joint\%20Statement_COVID-19.pdf, accessed on September 2020.

39 Ibid.

40 IMO, Circular Letter No. 4204/Add.14, 5 Mei 2020, Coronavirus (COVID-19) - Recommended Framework of Protocols for Ensuring Safe Ship Crew Changes and Travel during the Coronavirus (COVID-19) Pandemic. 
instrument specifically regulates state obligations during a pandemic, including the UNCLOS 1982. Although it does not regulate the rights and obligations of state in a pandemic situation, based on the principle of lex specialis derogate lex generali, state is bound by more specific legal instruments. In this case, the specific instrument is the IHR 2005.

The WHO managed the establishment of the IHR 2005. It aims to inform the world about public health and its risks and events. As an international agreement, the IHR 2005 legally binds 193 states parties, ${ }^{41}$ A WHO Member State can become a party to the 2005 IHR. The IHR 2005 is adopted at the $58^{\text {th }}$ World Health Assembly in Geneva, May 2005. It legally binds all the WHO member states that have not refused or made a reservation before December 2006. State reservations must not conflict objects and objectives of the new IHR.

The IHR 2005 consists of 66 articles and 9 attachments. The content is mostly related to capacity building, communication, and national action. There are varieties of provisions relating to a state's core capacity to detect, assess, notify, report, and respond to health risk events. Then, for communication, there are provisions for notification to the $\mathrm{WHO}$ and a two-way dialogue procedure involving states and the WHO. ${ }^{42}$ The existence of communication between state and the WHO will help the WHO to recognize the existence of a Public Health Emergency of International Concern (PHEIC) and issue recommendations. ${ }^{43}$ Regarding national actions that can be taken, the IHR 2005 provides governing health measures at port of entry, upon arrival and departure, ${ }^{44}$ and for tourists. ${ }^{45}$ The IHR 2005 also regulates health documents and financial costs associated with national action. ${ }^{46}$

The IHR 2005 adopts a principle known as free pratique. Based on Article 1 of the IHR 2005, free pratique is defined as a permit for a ship to enter port, to board or to disembark, and to unload or to load cargo. the IHR 2005 emphasizes that " $a$ ship or an aircraft shall not be prevented for public health reasons from calling at any point of entry". ${ }^{47}$

Article 28 (2) of the IHR 2005 specifically states that ships also may not be refused embarkation and dropping of passengers. According to Article 28 (3) of the IHR 2005, a state can allow a ship to enter its port if it will not cause spread of disease. This certainly leaves an exclusion gap in the case of certain public health risks or public health emergencies of international concern. Currently, the Covid-19 pandemic is one of them. Therefore, it can be interpreted that in a situation like this, state can prevent a ship from calling at its port and refuse embarkation and

\footnotetext{
41 The World Health Organization, Fifty-Eighth World Health Assembly: Resolutions and Decisions Annex, WHA58/2005/REC/1, Resolution WHA58.3.

Ibid., Articles 6, 7, 8, 9, 10, 11.

lbid., Articles 12 and 15.

Ibid., Articles 20, 21, 23.

lbid., Articles 30 and 31.

Ibid., Articles 40 and 41.

Article 28 (1), the IHR 2005.
} 
disembarkation of passengers. Nevertheless, state has lacks discretionary power of appreciation.

Action must meet the following requirements.

a. First, based on Article 43.1 of the IHR 2005, the action,

"shall not be more restrictive of international traffic and not more invasive or intrusive to persons that reasonably available alternatives that would achieve the appropriate level of health protection"

b. Second, based on Article 43.2 of the IHR 2005, state:

"shall base their determinations upon scientific research, available scientific evidence of a risk to human health, or where such evidence is insufficient, the available information including from WHO and other relevant intergovernmental organizations and international bodies, and any specific guidance or advice from WHO"

c. Finally, state must submit this justification to the WHO (Article 43.3) to allow the WHO to check that their actions do not interfere with international traffic. Following the assessment, WHO can ask state to reconsider implementing actions (Article 43.4).

The Covid-19 pandemic proves that state has control over all decisions regarding port access. Unquestionably, port can be a cluster of the spread of the Covid-19. In fact, refusing ships to enter port may not affect the spread of the pandemic at sea. Then again, at least state makes efforts to protect the health of its citizens from the disease.

\section{J. Conclusion}

An emergency, like the Covid-19 pandemic, may endanger national security. The port denials and restrictions policies do not violate international law, such as international treaty law and customary international law. Several international treaties - for instance, the UNCLOS 1982, the 1923 Port Convention, and the IHR 2005-provide opportunities for states to implement the policies. As mentioned earlier, the UNCLOS 1982 gave coastal state the right to determine its policies in internal waters, including ports. Then, the 1923 Port Convention allows states to deny access to ports in certain emergencies.

In addition to international agreements, customary international law also recognizes that state has full sovereignty over its ports. Therefore, the state has the right to grant or deny access to foreign ships to enter its ports. In spite of this, in emergencies, ships of foreign flags have the right to enter port. 
The Covid-19 pandemic situation has prompted many states to declare a state of emergency. The state of emergency gives privileges to states to form a system of interim government dealing with extreme situations that endanger national security. The existence of this state of emergency is related to the state's obligations to international law, international customary law that binds the state, and international treaty law that regulates restrictions on emergency powers to which the state is a party and is bound. Based on the discussions, international legal instruments that regulate limitation of power are usually legal instruments related to human rights.

Despite the fact that states have a right to close and limit their ports unilaterally, the UNCLOS 1982 mandates coastal states to carry out rescue and assistance to persons in distress at sea. However, the existing legal instruments do not clearly regulate place of safety. This could certainly be an opportunity for coastal states to refuse the designation as a safe haven and to allow rescue ships to dock in their ports. Therefore, in the current pandemic, sea rescue and assistance to persons in distress at sea to safety is a matter of debate due to an inadequate legal framework.

\section{References}

\section{Book}

Apostolopoulos, Yorghos (ed.), Population Mobility and Infectious Disease, Springer, Germany, 2007.

Caduff, Carlo, The Pandemic Perhaps: Dramatic Events in A Public Culture of Danger, University of California Press, California, 2015.

Last, John M. (ed.), A dictionary of Epidemiology, 4th edition, Oxford University Press, New York, 2001.

Oraa, Jaime, Human Rights in States of Emergency in International Law, Oxford University Press, United Kingdom, 1992.

Tanaka, Yoshifumi, The International Law of the Sea, Cambridge University Press, Cambridge, 2012.

\section{Other Documents}

Abdulkadir O. Abdulrazak and Sharifah Zubaidah Syed Abdul Kader, "Right of Ship Access to Port under International Law: All Bark with No Bite", Australian Journal of Basic and Applied Science, Vol. 6, No. 11, 2012.

A Joint Statement on the Response to the Covid-19 Outbreak between International Maritime Organization (IMO) and World Health Organization, 13 February 2020, http://www.imo.org/en/MediaCentre/HotTopics/Documents/Joint\%20Stateme nt_COVID-19.pdf, accessed on September 2020. 
Barnes, Richard, "The International Law of the Sea and Migration Control", in Bernard Ryan and Valsamis Mitsilegas (eds.), Extraterritorial Immigration Control: Legal Challenges, Martinus Nijhoff, Leiden, 2010.

Baumgartner, William D. and John T. Oliver, "Conditions on Entry of Foreign-Flag Vessels into US Ports to Promote Maritime Security", in Michael D. Cartsen, International Law and Military Operations, Naval War College, Rhode Island 2008.

Cambridge "Dictionary, of "State Emergency", https://dictionary.cambridge.org/dictionary/english/state-of-emergency>, accessed on May 2020.

Cohen, Nicole J., (et.al), "Travel and Border Health Measures to Prevent the International Spread of Ebola", Morbidity and Mortality Weekly Report (MMWR), Vol. 65, No. 3, 2016.

Davies, Sara E., "National Security and Pandemics", UN Chronicle, < https://www.un.org/en/chronicle/article/national-security-and-pandemics, accessed on September 2020.

DCAF, "State of Emergency", Backgrounder: Security Sector Governance and Reform, 2005.

Digest of U.S. Practice in International Law 2007, www.state.gov/documents/organization/147120/pdf, accessed on September 2020.

Emmons, Cassandra, "International Human Rights Law and COVID-19 State of Emergency", Verfassungsblog on Matters Consititutional, https://verfassungsblog.de/international-human-rights-law-and-covid-19states-of-emergency/, accessed on September 2020.

Greenfield, Patrick and Erin McCormick, "Coronavirus: Panama to Allow Cruise Liner Zaandam through Canal", https://www.theguardian.com/world/2020/mar/29/coronavirus-panama-toallow-cruise-liner-zaandam-through-canal, accessed on September 2020.

Grennan, Dara, "What is a Pandemic?", JAMA Patient Page, Vol. 321, No. 9, 2019. International Chamber of Shipping, "Coronavirus (COVID-19): Guidance for Ship Operators for the Protection of the Health of Seafarers", Version 1.0, 2020.

Letts, David, "Can the Law of the Sea Remain Afloat during Covid-19?", Australian National University, 2020, https://law.anu.edu.au/research/essay/covid-19and-international-law/can-law-sea-remain-afloat-during-covid-19, accessed on September 2020.

McGoldrick, Dominic, "The Interface between Public Emergency Powers and International Law", Oxford University Press and New York University School of Law, Vol. 2, No. 2, 2004.

Monelaar, Erik J., "Port and Coastal States" in Donald R. Rothwell (Ed.), (et.al), The Law of the Sea, Oxford University Press, United Kingdom, 2015. 
Papanicolopulu, Irini, "The Duty to Rescue at Sea, in Peacetime and in War: A General Overview", International Review of the Red Cross, Vol. 98, No. 2, 2016.

Simmons, Beth, "Civil Rights in International Law: Compliance with Aspects of the International Bill of Rights", Indiana Journal of Global Legal Studies, 2009.

Song, Fengxiang (et.al), “Emerging 2019 Novel Coronavirus 2019-nCov) Pneumonia", Radiology, Vol. 295, No. 1, 2020.

Oxman, B.H., "Human Rights and the United Nations Convention on the Law of the Sea" , Columbia Journal of Transnational Law, Vol. 36, 1997.

Ratcovich, Martin, "The Concept of 'Place of Safety': Yet Another Self-Contained Maritime Rule or a Sustainable Solution to the Ever-Controversial Question of Where to Disembark Migrants Rescued at Sea", Australian Year Book of International Law, Vol. 33, 2015.

Willhelmsen, "COVID-19 Global Port Restrictions Map", 2020, https://www.wilhelmsen.com/ships-

agency/campaigns/coronavirus/coronavirus-map/, accessed on June 2020.

World Health Organization (WHO), "Coronavirus Disease (Covid-19)", Situation Report-137, 2020.

"Collection of Sources on Entry into Port Under Force Majeure," 20012009.state.gov/s/I/2007/112701.htm, accessed on September 2020.

\section{Legal Documents}

American Convention on Human Rights (ACHR).

Case Concerning Military and Paramilitary Activities in and against Nicaragua (Nicaragua v. United States), 1986.

Convention and Statute on the International Regime of Maritime Ports 1923, adopted in Geneva on 9 December 1923 and entered into force on 26 July 1929.

European Convention on Human Rights (ECHR).

International Convenant on Civil and Political Rights (ICCPR), adopted on 16 December 1966 and entered info force on 23 March 1976 (in accordance with article 49, for all provisions except those of article 41); 28 March 1979 (for the provisions of article 41 - Human Rights Committee, in accordance with paragraph 2 of the said article 41).

International Convention on Maritime Search and Rescue (SAR), adopted on 27 April 1979 and entered into force on 22 June 1985. The last amendment was made in 2004 concerning persons in distress at sea, adopted in May 2004 and entered into force on 1 July 2006.

International Health Regulation (IHR) 2005 was adopted in Geneva on 23 May 2005 and entered into force on 15 June 2007.

International Maritime Organization, Circular Letter No. 4204/Add.14, 5 Mei 2020, Coronavirus (COVID-19) - Recommended Framework of Protocols for Ensuring 
Safe Ship Crew Changes and Travel during the Coronavirus (COVID-19) Pandemic.

International Maritime Organization (IMO), Resolution MSC. 167 (78), adopted on 20 May 2004

United Nations Convention on the Law of the Sea (UNCLOS) 1982 was adopted in Montego Bay on 10 December 1982 and entered into force on 16 November 1994.

World Health Organization, Fifty-Eighth World Health Assembly: Resolutions and

Decisions Annex, WHA58/2005/REC/1, Resolution WHA58.3.

\section{Acknowledgment}

This paper and the study would not have been possible without the exceptional support of the Law of the Sea lecturer, Achmad Gusman Catur Siswandi, SH, LL.M., Ph.D., who provided useful material and knowledge. Inspirations, knowledge, and materials in his class have provided significant contributions. In addition, systematical thinking and scientific writing are the most prominent training in his class. The gratitude is also extended to Dr. Gulardi Nurbintoro, Renny Meirina, SH, LL.M., and Nova Maulani SH, LL.M., from the Directorate for Legal Affairs and Territorial Treaties (the Ministry of Foreign Affairs of the Republic of Indonesia). Their supervision and discussions have made this article topic available. This study also gained support from Shannon Suryaatmadja for partial translation and editing of the submitted draft. 